\title{
Genetic diversity and comparison of physicochemical and nutritional characteristics of six quinoa (Chenopodium quinoa willd.) genotypes cultivated in Chile
}

\author{
Diversidade genética e comparação das características físico-químicas e nutricionais \\ de seis genótipos de quinoa (Chenopodiumquinoa Willd.) cultivados no Chile \\ Margarita MIRANDA ${ }^{1}$, Antonio VEGA-GÁLVEZ ${ }^{1,2 *}$, Enrique MARTINEZ ${ }^{2}$, Jéssica LÓPEZ ${ }^{1,3}$, \\ María José RODRÍGUEZ ${ }^{1}$, Karem HENRÍQUEZ ${ }^{4}$, Francisco FUENTES ${ }^{5}$
}

\begin{abstract}
The present study was focused on the analysis of agronomical, nutritional, physicochemical, and antioxidant properties of six genetically different quinoa (Chenopodium quinoa Willd) genotypes cultivated in three distinctive geographical zones of Chile. Ancovinto and Cancosa genotypes from the northern Altiplano $\left(19^{\circ} \mathrm{S}\right)$, Cáhuil and Faro from the central region $\left(34^{\circ} \mathrm{S}\right)$, and Regalona and Villarica from the southern region $\left(39^{\circ} \mathrm{S}\right)$ are representative of high genetic differentiation among the pooled samples, in particular between Altiplano and the centralsouthern groups. A Common-Garden Assay at $30^{\circ} \mathrm{S}$ showed significant differences among seed origins in all morphometric parameters and also in yields. Altiplano genotypes had larger panicule length but no seed production. A significant influence of the different quinoa genotypes on chemical composition and functional properties was also observed. Protein concentration ranged from 11.13 to $16.18 \mathrm{~g} .100 \mathrm{~g}{ }^{-1} \mathrm{~d}$.m., while total dietary fiber content ranged from 8.07-12.08 g.100 g-1 d.m., and both were the highest in Villarrica ecotype. An adequate balance of essential amino acids was also observed. Sucrose was the predominant sugar in all genotypes. Antioxidant activity was high in all genotypes, and it was highest in Faro genotype (79.58\% inhibition).

Keywords: quinoa; antioxidant activity; amino acids; functional properties.
\end{abstract}

\section{Resumo}

O presente estudo teve como objetivo a análise das propriedades agronômicas, físicas, nutricionais e antioxidantes de seis genótipos diferentes de quinoa (Chenopodium quinoa Willd), cultivados em três distintas zonas geográficas do Chile. Ancovinto e Cancosa, provenientes do norte do Altiplano $\left(19^{\circ} \mathrm{S}\right)$, Cahuil e Faro, originários do centro $\left(34^{\circ} \mathrm{S}\right)$, e Regalona e Villarica, do sul (39 $\left.{ }^{\circ} \mathrm{S}\right)$, foram representativos da alta diferenciação genética das amostras combinadas, em particular entre Altiplano e os grupos centro-sul. O ensaio do jardim de coleção a $30^{\circ} \mathrm{S}$ mostrou diferenças significativas entre as origens das sementes em todos os parâmetros morfométricos e também nos rendimentos. Os genótipos do Altiplano apresentaram uma panícula de maior comprimento, mas sem produção de sementes. Também se observou uma influência significativa dos genótipos diferentes de quinoa na composição química e propriedades funcionais. A concentração de proteína variou de 11,13 a 16,18 g. $100 \mathrm{~g}^{-1}$ d.m., enquanto o conteúdo de fibra alimentar total de 8,07-12,08 g.100 g-1 de d.m., sendo ambos mais elevados no ecotipo Villarrica. Também se observou um equilíbrio adequado de aminoácidos essenciais. A sacarose foi o açúcar dominante em todos os genótipos. A atividade antioxidante foi alta em todos os genótipos, sendo maior no Faro (79,58\% de inibição).

Palavras-chave: quinoa; atividade antioxidante; aminoácidos; propriedades funcionais.

\section{Introduction}

Quinoa (Chenopodium quinoa Willd) is a staple food from ancient civilizations, characterized by being a stress-tolerant plant with ecotypes growing well in soils with high salinities (RUIZ-CARRASCO et al., 2011), at high altitudes and poor soils, with limited rainfall or under extremely low irrigation (MARTÍNEZ et al., 2009; FUENTES; BHARGAVA, 2011). This highly nutritive grain is traditionally grown in the Andean highlands of Peru, Bolivia, Ecuador, Chile, Argentina, and Colombia (ABUGOCH, 2009).
In Chile, quinoa has survived from extinction in three very different agro-ecological areas. Its conservation reveals a rich biodiversity, where landraces can grow in very different environments, from the extremely dry Altiplano highlands at $4000 \mathrm{~m}$ above sea level $\left(19^{\circ} \mathrm{S}\right)$ with average rainfall of $150 \mathrm{~mm}$ per year (maximum $300 \mathrm{~mm}$ ) to coastal zones of central $\left(35^{\circ} \mathrm{S}\right)$ and southern Chile $\left(39^{\circ} \mathrm{S}\right)$, where soils are clayish but rainfall is above $1000 \mathrm{~mm}$ /year (MARTÍNEZ et al., 2007, 2009). The most remarkable attribute of quinoa seeds is their protein content. However, they are also a good source of dietary fiber,

Received 24/1/2012

Accepted 28/8/2012 (005576)

${ }^{1}$ Department of Food Engineering, Universidad de La Serena, Av. Raúl Bitrán, s/n, Box 599, La Serena, Chile, e-mail: avegag@userena.cl

${ }^{2}$ Program on Applied Biology and Ecology, Centro de Estudios Avanzados en Zonas Áridas, Facultad de ciencias del mar, Universidad Católica del Norte, sede, Coquimbo, Chile

${ }^{3}$ Department of Science and Food Technology, Faculty of Technology, University of Santiago de Chile - USACH, Obispo Umaña 050, Santiago, Chile

${ }^{4}$ Departament of Food Science, Nutrition and Dietetic, University of Concepción, Concepción

${ }^{5}$ Departamento de Agricultura del Desierto y Biotecnología, Universidad Arturo Prat, Iquique, Chile

${ }^{*}$ Corresponding author 
minerals, oils, vitamins in low concentrations, antioxidants, and the whole set of essential amino acids (REPO-CARRASCO; ESPINOZA; JACOBSEN, 2003; VEGA-GÁLVEZ et al., 2010b). The composition of dietary fiber in common cereals, like wheat, rye, and oat is well known. However, there exists very little information about the dietary fiber of the native Andean crops, like amaranth or quinoa (REPO-CARRASCOVALENCIA et al., 2009b). The three main types of polyphenols are flavonoids, phenolic acids, and tannins, which act as powerful antioxidants in vitro. These compounds are considered to carry many potential beneficial health effects (REPOCARRASCO-VALENCIA et al., 2010). Very little information exists concerning polyphenols and antioxidant activity in Andean grains such as quinoa. However, the evaluation of food antioxidant activity is considered as an important step prior to the definition of the antioxidant phytochemical nature they contain. This is so because the consumption at high scale of many plants has been recommended from the viewpoint of their high antioxidant potency (DINI; TENORE; DINI, 2010). This study would contribute to further knowledge related to the nutritional content of these plant materials in order to define appropriate functional properties for food applications and their relevance as potential sources of dietary antioxidants.

This article focuses on the study of quinoa seeds cultivated in the three geographic zones in Chile mentioned above in order to evaluate the genetic diversity of the seed-source regions and the agronomical differences under a common garden assay at intermediate latitude. In addition, we established the difference among six ecotypes from the three regions where quinoa is still cultivated in Chile, with respect to their nutritional and functional properties, particularly proteins, ash, sugars content, total dietary fiber, 2,2,-diphenyl-2-picryl-hydrazyl (DPPH), amino acids composition, and antioxidant activity.

\section{Material and methods}

\subsection{Analysis of genetic diversity in the seed origin zones}

The genetic diversity of quinoa seeds was characterized by analyzing the allelic richness and allele sharing among the quinoa germplasm from the three main production zones of Chile by using 20 polymorphic microsatellite (SSR), as described by Fuentes et al. (2009). Representative germplasm/seed stock from the northern Altiplano (18-22 $\left.{ }^{\circ} \mathrm{S}, n=28\right)$, central Chile (34-36 ${ }^{\circ} \mathrm{S}, n=7$ ) and southern Chile (37-39 ${ }^{\circ} \mathrm{S}, n=21$ ) were obtained from Arturo Prat University (UNAP), Agricultural Research Institute (INIA), and Baer Seeds Company seed banks, respectively. Seed samples were sown, their DNA was obtained from the leaves, and the 20 SSR loci was amplified as reported by Fuentes et al. (2009).

\subsection{Agronomic behavior of the six ecotypes under a common garden assay}

Six selected landraces (seeds of the harvest season of 2010), two from each production zone, were chosen for the chemical analysis and evaluation of their functional properties. These sources were: two northern Altiplano landraces, Ancovinto and Cancosa (from around $19^{\circ} \mathrm{S}$ ), two landraces from central regions, Cáhuil and Faro (from around $34^{\circ} \mathrm{S}$ ), and two southern quinoa, Regalona (official variety) and Villarrica landrace (from around $\left.39^{\circ} \mathrm{S}\right)$. Seeds were sown in Vicuña $\left(30^{\circ} \mathrm{S}, 70^{\circ} \mathrm{W}\right)$ at 657 meters above sea level, in October 2010, on six randomly distributed parcels, with surface of $448 \mathrm{~m}^{2}$ each. The sowing density was of $4 \mathrm{~kg} \mathrm{ha}^{-1}$ into 16 furrows of 40 meters in length at $2 \mathrm{~cm}$ depth. Soils of this field station contained NPK in the ratio of $90: 20: 200\left(\mathrm{mg} \mathrm{kg}^{-1}\right), 2-3 \%$ of organic matter, 2.1 to $4.6 \mathrm{dS} \mathrm{m} \mathrm{m}^{-1}$ of electric conductivity, and $\mathrm{pH}$ between 6.6 and 7.0, which are appropriate for quinoa cultivation at this latitude (MARTÍNEZ et al., 2009). Weed control was managed by hand removal when required. The crop was irrigated once a week for two hours until reaching field capacity, and the seeds were harvested in April 2011. Plant height $(\mathrm{cm})$, width and length of panicules $(\mathrm{cm})$, and plant and seed dry biomass $(\mathrm{g})$ were measured at the end of the harvest season for 15 plants of each genotype, randomly taken from each parcel. Harvest index (\%) was estimated as the ratio of seeds to whole plant dry-biomass. Yields were estimated from grain production per plant $(n=15)$ and mean plant density per hectare and were evaluated in triplicate for the six parcels of $448 \mathrm{~m}^{2}(\mathrm{n}=18)$.

\subsection{Chemical-analytical procedures}

\section{Sample preparation and proximate analysis}

The samples were analyzed without a dehusking treatment, so that they were only visually inspected to discard contaminant particles or impurities. Analytical determinations were carried out with quinoa seeds triturated in a grinder (MC0360, UFESA, Zhejiang, China).

The moisture content was determined by AOAC method $\mathrm{n}^{\circ} 934.06$ (ASSOCIATION..., 1990) using a vacuum oven (Gallenkamp, OVL570, Leicester, UK) and an analytical balance with an accuracy of $\pm 0.0001 \mathrm{~g}$ (CHYO, Jex120, Japan). The crude protein content was determined using the Kjeldahl method with a conversion factor of 6.25 (AOAC $\mathrm{n}^{\circ}$. 960.52). The lipid content was analyzed gravimetrically following Soxhlet extraction (AOAC n. 960.39). The crude fiber was estimated by acid/alkaline hydrolysis of insoluble residues (AOAC $n^{\circ}$. 962.09). The crude ash content was estimated by incineration in a muffle furnace at $550^{\circ} \mathrm{C}\left(\mathrm{AOAC} \mathrm{n}^{\circ} .923 .03\right)$. All methodologies followed the recommendations of the Association of Official Analytical Chemists (ASSOCIATION..., 1990), and all the analyses were performed in triplicate and the results were expressed as g. $100 \mathrm{~g}^{-1}$ dry matter (d.m.).

\section{Determination of total dietary fiber (TDF)}

The total dietary fiber was determined by the gravimetricenzymatic method ( $n^{\circ}$ 985.29) suggested by the Official Method of Analysis (ASSOCIATION..., 1990) using a Total Dietary Fiber Assay Kit (TDF100A; Sigma-Aldrich). The basis of this method is the isolation of dietary fiber by enzymatic digestion from the rest of the material constituents. The residue was measured gravimetrically. Samples were suspended in phosphate buffer, $0.08 \mathrm{M}, \mathrm{pH} 6.0$ and digested sequentially 
with heat-stable $\alpha$-amylase at $95-100{ }^{\circ} \mathrm{C}$, protease at $60{ }^{\circ} \mathrm{C}$, and amyloglucosidase at $60{ }^{\circ} \mathrm{C}$. Four volumes of $95 \%$ ethanol preheated at $60^{\circ} \mathrm{C}$ were added to precipitate the soluble dietary fiber. After 1 hour, the residue was filtered through tarred fritted glass crucibles. The crucibles containing TDF were rinsed with dilute alcohol followed by acetone and dried overnight in a $105{ }^{\circ} \mathrm{C}$ oven. Half of the samples were analyzed for protein (Kjeldahl nitrogen $\times 6.25$ ), and the others were ashed in a muffle furnace at $525^{\circ} \mathrm{C}$ for 5 hours. Total dietary fiber is the weight of the residue minus the weight of the protein and ash. TDF was expressed as g. $100 \mathrm{~g}^{-1}$ d.m.

\section{Determination of sugars}

The carbohydrates (fructose, glucose, and sucrose) were quantified by high performance thin-layer chromatography (HPTLC) according to Patzsch, Netz and Funk (1988), with light modifications following the plate preparation, separation, and derivatization performed by Aranda, Vega and Villegas (2005). All the analyses were performed in triplicate. The components were expressed as g. $100 \mathrm{~g}^{-1} \mathrm{~d} . \mathrm{m}$.

\section{Determination of fatty acid composition}

Fatty acid composition was determined by conversion to fatty acid methyl esters (FAME), followed by gas chromatography equipped with a flame ionization detector (FID) and an integrator. A polar capillary column was used, and helium was the carrier gas. The FID and injector temperatures were both maintained at $220^{\circ} \mathrm{C}$. FAME peaks were identified by comparing the retention times with standards (component FAME mix) from Sigma-Aldrich, St. Louis, US (NYAM et al., 2009).

\section{Determination of essential amino acids}

All amino acids, except for cystine and tryptophan, were determined by an HPLC system and an UV detector, and the samples were hydrolyzed in $6 \mathrm{M} \mathrm{HCl}$ for 22 hours under nitrogen, buffered to $\mathrm{pH} 2.2$, and injected onto the HPLC system with post-column ninhydrin derivatization. Norleucine was used as an internal standard (WRIGHT et al., 2002).

\section{Determination of antioxidant activity}

Free radical scavenging activity of the samples was determined using the 2,2,-diphenyl-2-picryl-hydrazyl (DPPH) method (TURKMEN; SARI; VELIOGLU, 2005) with some modifications. Different dilutions of the extracts were prepared in triplicate. An aliquot of $2 \mathrm{~mL}$ of $0.15 \mathrm{mM} \mathrm{DPPH}$ radical in ethanol was added to a test tube with $1 \mathrm{~mL}$ of the sample extract. The reaction mixture was vortex-mixed for $30 \mathrm{~s}$ and left to stand at ambient temperature in the dark for 20 minutes. The absorbance was measured at $517 \mathrm{~nm}$ using a spectrophotometer

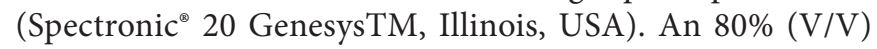
ethanol was used to calibrate the spectrophotometer. The control sample was prepared without adding extract. All solvents and reagents were purchased from Sigma (Sigma Chemical CO., St. Louis, MO, USA). The DPPH radicals scavenging rate of sample was calculated as percent inhibition relative to control using the following equation and expressed as percentage inhibition (Equation 1):

$$
\text { Inhibition } \%=\left(1-\frac{A b s_{\text {sample }}}{A b s_{\text {control }}}\right) * 100
$$

where $\mathrm{Abs}_{\text {sample }}$ is the absorbance with sample and $\mathrm{Abs}_{\text {control }}$ is the absorbance without sample.

\subsection{Statistical analyses}

For the genetic survey among representative germplasm/ seed stock of the three geographic zones, a Principal Component Analysis (PCA) was performed with a covariance matrix from similarity dataset based on the 20 SSR markers using the statistical software INFOSTAT (INFOSTAT, 2008). ANOVA was used to test the parameters measured in the harvested plants in the field test (common garden assay) for the six genotypes. The mean values of each parameter were used to make multiple comparisons using Tukey's test at $p<0.05$ of significance.

Determinations in triplicate were used for all chemical analysis. All data were expressed as mean \pm standard deviation (SD). Data analysis was performed using Statgraphics ${ }^{\otimes}$ Plus 5 (Statistical Graphics Corp., Herndon, VA, USA). A significance test was performed using the Fisher's least significant difference (LSD) method; differences were taken as statistically significant when $p<0.05$ (confidence level of 95\%). The Multiple Range Test (MRT) included in the statistical program was used to prove the existence of homogeneous groups within each of the parameters analyzed.

\section{Results and discussion}

\subsection{Genetic analysis}

Genetic differences showed uniform heterozygosity among the geographical zones (north: 9.6; center: 11.4; and south: 11.8) but poor allele sharing among the three geographical areas of ancestral quinoa production (Figure 1). Particularly, the northern Altiplano group did not have any shared genotypes with the central-southern groups. Between these centralsouthern groups, some seed exchange might be more similar to the northern ecotypes, as also suggested by Fuentes et al. (2009). The morphometric and agronomic results confirm such differences. Thus, plant morphology, particularly panicule length and width, were significantly different between the northern and central-southern groups (Table 1). The panicules of both northern Altiplano ecotypes (Ancovinto and Cancosa) did not reach maturity (very low harvest index, Table 1). It seems that at high latitudes (at $30^{\circ} \mathrm{S}$ and perhaps above $25^{\circ} \mathrm{S}$ ), the plants from the northern regions do not bear fruits at all or the yields are extremely low. Likewise, it was observed that the central and southern genotypes did not differ significantly $(p<0.05)$ for seed diameter and showed the lowest values of 1000 seed weight, whereas Ancovinto genotype showed the lowest values of seed diameter and the highest values of 1000 seed weight (Table 1). This observation is confirmed by the high genetic differences found among the northern and the 


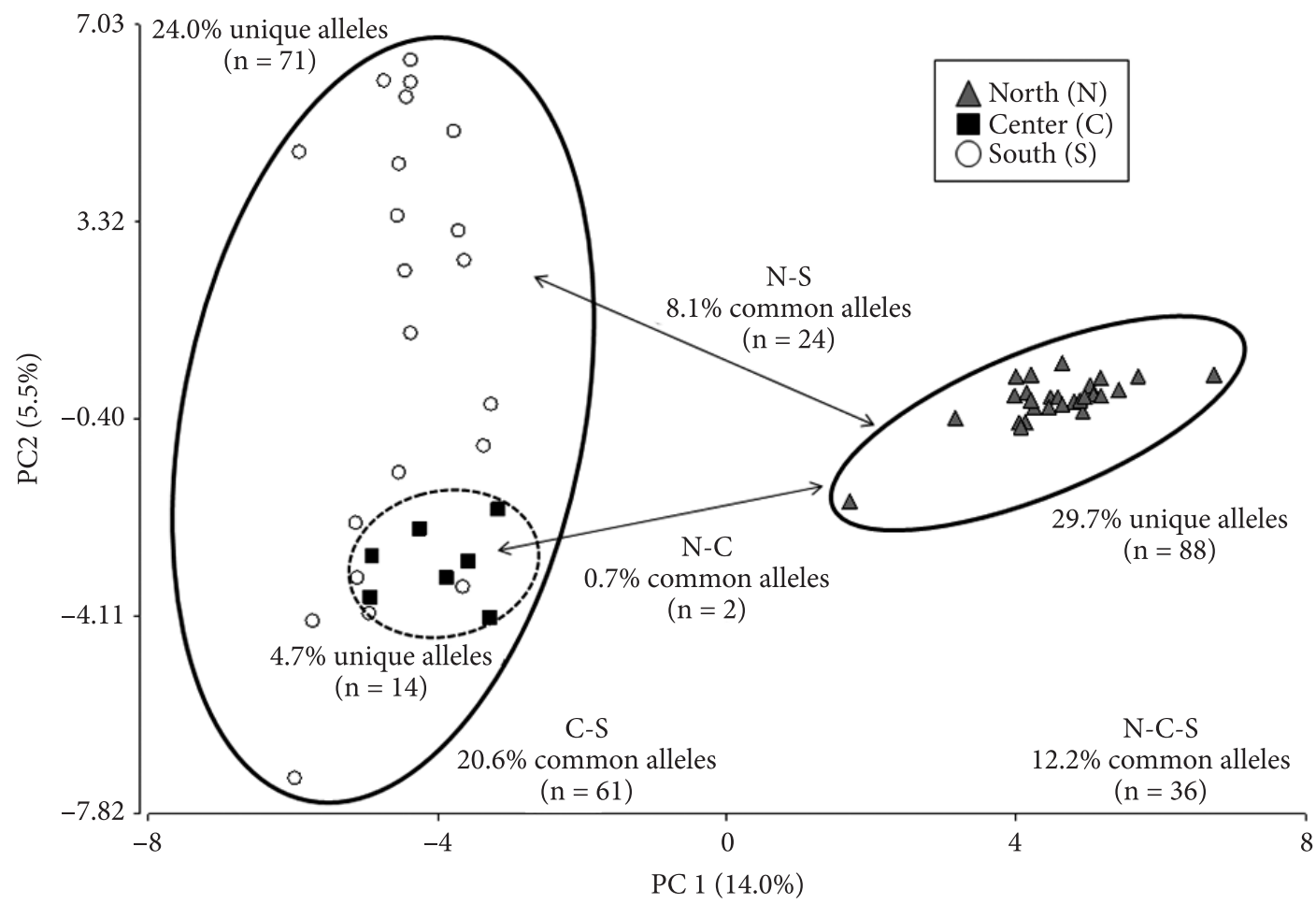

Figure 1. Genetic separation in three zones or genetic pools (Northern, Central, and Southern genotypes) as revealed by Principal Component Analysis performed on 20 polymorphic microsatellite loci.

Table 1. Morphometric and yield responses of six quinoa genotypes tested in a common garden assay at $30^{\circ} \mathrm{S}$.

\begin{tabular}{llccccccc}
\hline \multicolumn{1}{c}{ Genotypes } & $\begin{array}{c}\text { Plant length } \\
(\mathrm{cm})\end{array}$ & $\begin{array}{c}\text { Panicule lenght } \\
(\mathrm{cm})\end{array}$ & $\begin{array}{c}\text { Panicule width } \\
(\mathrm{cm})\end{array}$ & $\begin{array}{c}\text { Harvest index } \\
(\%)\end{array}$ & $\begin{array}{c}\text { Yields } \\
(\text { ton/ha })^{*}\end{array}$ & $\begin{array}{c}\text { Seed diameter } \\
(\mathrm{mm})^{1}\end{array}$ & $\begin{array}{c}1000 \text { seed weight } \\
(\mathrm{g})^{1}\end{array}$ \\
\hline North & Ancovinto & $154.20 \pm 15.55^{\mathrm{a}}$ & $34.13 \pm 6.56^{\mathrm{a}}$ & $4.43 \pm 1.13^{\mathrm{a}}$ & $0.86 \pm 2.86^{\mathrm{a}}$ & $0.34 \pm 1.22^{\mathrm{a}}$ & $1.44 \pm 0.13^{\mathrm{a}}$ & $4.72 \pm 0.08^{\mathrm{a}}$ \\
& Cancosa & $155.20 \pm 19.36^{\mathrm{a}}$ & $35.40 \pm 5.37^{\mathrm{a}}$ & $5.27 \pm 1.15^{\mathrm{a}}$ & $2.86 \pm 2.32^{\mathrm{a}}$ & $0.80 \pm 0.61^{\mathrm{a}}$ & $2.15 \pm 0.19^{\mathrm{b}}$ & $4.20 \pm 0.07^{\mathrm{b}}$ \\
Centre & Cáhuil & $138.40 \pm 20.84^{\mathrm{b}}$ & $16.07 \pm 4.22^{\mathrm{b}}$ & $9.20 \pm 2.18^{\mathrm{b}}$ & $31.73 \pm 8.24^{\mathrm{b}}$ & $5.35 \pm 2.58^{\mathrm{b}}$ & $1.86 \pm 0.26^{\mathrm{c}}$ & $3.36 \pm 0.10^{\mathrm{c}}$ \\
& Faro & $106.69 \pm 12.40^{\mathrm{c}}$ & $21.93 \pm 4.18^{\mathrm{c}}$ & $8.53 \pm 2.03^{\mathrm{b}}$ & $44.32 \pm 3.51^{\mathrm{c}}$ & $8.09 \pm 4.58^{\mathrm{c}}$ & $1.70 \pm 0.17^{\mathrm{c}}$ & $3.07 \pm 0.08^{\mathrm{d}}$ \\
\multirow{5}{*}{ South } & Regalona & $103.13 \pm 14.89^{\mathrm{c}}$ & $19.73 \pm 6.16^{\mathrm{b}, \mathrm{c}}$ & $7.80 \pm 3.17^{\mathrm{b}}$ & $35.61 \pm 8.70^{\mathrm{b}, \mathrm{d}}$ & $6.35 \pm 2.43^{\mathrm{b}, \mathrm{c}}$ & $1.79 \pm 0.10^{\mathrm{c}}$ & $3.05 \pm 0.09^{\mathrm{d}}$ \\
& Villarrica & $99.38 \pm 11.20^{\mathrm{c}}$ & $19.47 \pm 3.78^{\mathrm{b}, \mathrm{c}}$ & $10.67 \pm 1.72^{\mathrm{c}}$ & $38.79 \pm 6.40^{\mathrm{c}, \mathrm{d}}$ & $5.99 \pm 3.24^{\mathrm{b}}$ & $1.84 \pm 0.11^{\mathrm{c}}$ & $3.00 \pm 0.05^{\mathrm{d}}$ \\
\hline
\end{tabular}

*Yields were estimated from plant density and average of grams of grains per plant. ${ }^{1}$ Data are means \pm SD of ten replicates. ab,c,different letters in the same columns indicate that the values are significantly different $(p<0.05)$.

central-southern groups. It is very likely that such contrasting features are due to different responses to day length during the sow-to-harvest period and probably to more sensibility to higher temperatures (BERTERO; KING; HALLA, 1999; FUENTES; BHARGAVA, 2011). Similar results had been observed before for other landraces collected from the same three regions (MARTÍNEZ; DELATORRE; VON BAER, 2007).

\subsection{Proximate analysis}

The proximate analysis for the six quinoa ecotypes (Table 2) showed significant differences among the three geographic zones $(p<0.05)$. The moisture content of the six genotypes ranged between 7.7 g. $100 \mathrm{~g}^{-1}$ d.m. (Ancovinto) and $15.17 \mathrm{~g} .100 \mathrm{~g}^{-1} \mathrm{~d}$.m. (Villarrica). As expected, there was lower moisture content in the northern zone compared with that of the central and southern zones. Knowledge of the moisture content may partly be useful in the determination of the stability of stored seed. In the literature, moisture values for quinoa range from 8.2-16.6 g.100 g ${ }^{-1}$ d.m. (CHAUHAN; ESKIN; TKACHUK, 1992; DINI; TENORE; DINI, 2005; MIRANDA et al., 2010; REPO-CARRASCO-VALENCIA et al., 2010; WRIGHT et al., 2002). The highest ash content was found in the southern zone. The ash content of quinoa obtained (3.18-3.70 g.100 g-1 d.m.) is similar to those reported by some authors (JANCUROVÁ; MINAROUICOVÁ; DANDÁR, 2009; MIRANDA et al., 2010), and higher than that reported by Repo-Carrasco-Valencia et al. (2010) (2.27-3.12 g.100 g $\mathrm{g}^{-1}$ d.m.) and Chauhan, Eskin and Tkachuk (1992) (2.82 g.100 g ${ }^{-1}$ d.m.).

Quinoa is also considered as one of the best protein sources in the vegetable kingdon; therefore, it has a potential as a protein substitute for food and fodder and also in the pharmaceutical industry (VEGA-GÁLVEZ et al., 2010a). Protein content 
Table 2. Proximate composition, total dietary fiber, and sugar content of quinoa genotypes (g. $100 \mathrm{~g}^{-1} \mathrm{~d} . \mathrm{m}$.).

\begin{tabular}{|c|c|c|c|c|c|c|}
\hline \multicolumn{7}{|c|}{ Genotypes } \\
\hline & \multicolumn{2}{|c|}{ North } & \multicolumn{2}{|c|}{ Centre } & \multicolumn{2}{|c|}{ South } \\
\hline & Ancovinto & Cancosa & Cáhuil & Faro & Regalona & Villarrica \\
\hline Moisture & $7.77 \pm 0.05^{\mathrm{a}}$ & $9.25 \pm 0.03^{\mathrm{b}}$ & $13.18 \pm 0.01^{\mathrm{c}}$ & $13.12 \pm 0.07^{\mathrm{c}}$ & $14.29 \pm 0.01^{\mathrm{c}}$ & $15.17 \pm 0.02^{\mathrm{d}}$ \\
\hline Ash & $3.39 \pm 0.02^{\mathrm{a}}$ & $3.51 \pm 0.01^{\mathrm{b}}$ & $3.18 \pm 0.04^{c}$ & $3.51 \pm 0.03^{b}$ & $3.66 \pm 0.04^{\mathrm{d}}$ & $3.70 \pm 0.03^{\mathrm{d}}$ \\
\hline Protein (Nx6.25) & $13.01 \pm 0.14^{\mathrm{a}}$ & $13.64 \pm 0.01^{\mathrm{b}}$ & $11.13 \pm 0.35^{c}$ & $11.43 \pm 0.06^{c}$ & $14.44 \pm 0.11^{\mathrm{d}}$ & $16.18 \pm 0.10^{\mathrm{e}}$ \\
\hline Fat & $6.20 \pm 0.01^{\mathrm{a}}$ & $5.95 \pm 0.04^{\mathrm{b}}$ & $7.06 \pm 0.03^{c}$ & $6.65 \pm 0.02^{\mathrm{d}}$ & $6.37 \pm 0.01^{\mathrm{e}}$ & $5.57 \pm 0.01^{\mathrm{f}}$ \\
\hline Crude fiber & $1.51 \pm 0.06^{\mathrm{a}}$ & $1.81 \pm 0.06^{\mathrm{b}}$ & $1.21 \pm 0.02^{c}$ & $1.55 \pm 0.06^{\mathrm{a}}$ & $1.83 \pm 0.01^{\mathrm{b}}$ & $2.85 \pm 0.04^{\mathrm{d}}$ \\
\hline Total carbohydrates* & $68.12 \pm 0.05^{\mathrm{a}}$ & $65.84 \pm 0.01^{\mathrm{b}}$ & $64.24 \pm 0.26^{c}$ & $63.75 \pm 0.05^{\mathrm{d}}$ & $59.42 \pm 0.17^{\mathrm{e}}$ & $56.54 \pm 0.01^{\mathrm{f}}$ \\
\hline Total dietary fiber & $9.40 \pm 0.09^{\mathrm{a}}$ & $8.07 \pm 0.32^{\mathrm{b}}$ & $9.85 \pm 0.20^{c}$ & $8.47 \pm 0.42^{\mathrm{b}}$ & $10.38 \pm 0.18^{c}$ & $12.08 \pm 0.32^{\mathrm{d}}$ \\
\hline Fructose & $0.26 \pm 0.03^{\mathrm{a}}$ & $0.20 \pm 0.02^{\mathrm{a}}$ & $0.22 \pm 0.02^{\mathrm{a}}$ & $0.12 \pm 0.01^{\mathrm{b}}$ & $0.12 \pm 0.01^{\mathrm{b}}$ & $0.12 \pm 0.02^{\mathrm{b}}$ \\
\hline Glucose & $0.40 \pm 0.03^{\mathrm{a}}$ & $0.20 \pm 0.01^{\mathrm{b}}$ & $0.15 \pm 0.01^{\mathrm{c}}$ & $0.11 \pm 0.01^{\mathrm{c}}$ & $0.17 \pm 0.01^{c}$ & $0.12 \pm 0.03^{c}$ \\
\hline Sucrose & $3.00 \pm 0.14^{\mathrm{a}}$ & $2.52 \pm 0.36^{\mathrm{a}}$ & $3.00 \pm 0.21^{\mathrm{a}}$ & $2.71 \pm 0.16^{\mathrm{a}}$ & $2.96 \pm 0.08^{\mathrm{a}}$ & $3.05 \pm 0.58^{\mathrm{a}}$ \\
\hline
\end{tabular}

${ }^{\star}$ Calculated from mean values by difference. ${ }^{\mathrm{a}, \mathrm{b}, \mathrm{b}, \mathrm{d}, \mathrm{d}}$ Different letters in the same lines indicate that the values are significantly different $(p<0.05)$.

was detected in quinoa genotypes and it ranged between 11.13 g. $100 \mathrm{~g}^{-1}$ d.m and 16.18 g. $100 \mathrm{~g}^{-1}$ d.m. (Table 2). This value is similar to that reported by Repo-Carrasco-Valencia et al. (2010), who found values between 11.32 and $14.72 \mathrm{~g} .100 \mathrm{~g}^{-1} \mathrm{~d}$.m. when working with six genotypes of quinoa from Peru. This protein content was also significantly affected by location; Regalona and Villarrica genotypes (both from southern zones) showed the highest total protein content. Cáhuil genotypes has a significantly higher content of fat (Table 2) as compared to the other five genotypes, but it is similar to those reported by Wright et al. (2002) when investigating different quinoa genotypes (6.2 g. $100 \mathrm{~g}^{-1}$ d.m. for Garden orach, $5.3 \mathrm{~g} .100 \mathrm{~g}^{-1}$ d.m. for Sweet quinoa, and 5.7 g. $100 \mathrm{~g}^{-1}$ d.m. for Bitter quinoa).

A high value of crude fiber was found for the southern Villarrica genotypes $\left(2.85\right.$ g. $100 \mathrm{~g}^{-1}$ d.m.). The range of crude fiber content for the quinoa genotypes was similar to those reported by some researchers (CHAUHAN; ESKIN; TKACHUK, 1992; MIRANDA et al., 2010), but lower as compared with other studies such as those of Dini, Tenore and Dini (2005) (12.3 g.100 g ${ }^{-1}$ d.m.). The main component of all six ecotypes was carbohydrates, which was calculated by difference; the variation in carbohydrate contents for different ecotypes is attributed to the differences in the contents of other constituents.

\subsection{Determination of Total Dietary Fiber (TDF)}

The results of total dietary fiber (TDF) determinations are shown in Table 2 . The content of total dietary fiber in Villarrica genotype was the highest (12.08 g.100 g ${ }^{-1}$ d.m.), followed by Regalona (10.38 g.100 g ${ }^{-1}$ d.m.), which is also from the southern zone, as compared to the other genotypes studied $\left(<9.85\right.$ g. $100 \mathrm{~g}^{-1}$ d.m.). One possible explanation is the genetic differences such as plants defense mechanism during development, as pointed out by Torrez, Guzmán and Carvajal (2002). The environmental differences in the southern zone (for Regalona and Villarrica genotypes) are soils, which are strongly affected by volcanic activity. In addition, these variations might be explained by different temperatures and rainfall regimes, as well as by the use of chemical fertilizers (normally not used except for Regalona variety), or they may be due to the natural nutrient content of the soils, among other factors (BARIKMO; AUATTARA; OSHAUG, 2004). TDF content was similar to the content found by Wright et al. (2002), 8.8-12.1 g.100 g $\mathrm{g}^{-1} \mathrm{~d} . \mathrm{m}$ for three quinoa genotypes (Garden orach, Sweet quinoa, and Bitter quinoa), and to those reported by Repo-Carrasco-Valencia et al. (2009b), ranging between 8.51-16.37 g.100 g $\mathrm{g}^{-1}$ d.m. for two varieties of kiwicha (Amaranthus caudatus); however, it was lower as compared with other studies such as that of Repo-Carrasco-Valencia and Serna (2011), who found 13.5615.99 g. $100 \mathrm{~g}^{-1} \mathrm{~d} . \mathrm{m}$ for four quinoa varieties.

\subsection{Determination of sugars}

The amounts of fructose, glucose, and sucrose in the genotypes are given in Table 2. The concentrations of mean fructose and glucose among the genotypes were found to be significantly different $(p<0.05)$, but sucrose contents were not found statistically different among the genotypes $(p<0.05)$. As shown in Table 2, sucrose showed higher concentrations compared with other sugars in all experimental genotypes, followed by glucose (0.11-0.40 g.100 $\mathrm{g}^{-1}$ d.m.) and fructose (0.12-0.26 g.100 g $\mathrm{g}^{-1}$ d.m.). Sucrose content varied between 2.52 and 3.05 g. $100 \mathrm{~g}^{-1}$ d.m., values obtained from Cancosa and Villarrica genotypes, respectively. These data are in accordance with those reported by Miranda et al. (2010) and Repo-Carrasco, Espinoza and Jacobsen (2003). However, Dini, Tenore and Dini (2005), working with variety of quinoa called Kancolla, reported lower sucrose content ( 1.85 g.100 g ${ }^{-1}$ d.m.). Ancovinto genotype showed the highest mean contents of fructose and glucose, in contrast to Cáhuil and Villarrica genotypes, which had the highest mean sucrose content.

\subsection{Determination of fatty acids}

An important feature of the composition of the quinoa is its fat content. Data about the composition of fatty acids are summarized in Table 3 . There was also a significant variation in fatty acid profile among the six genotypes $(p<0.05)$. These differences might be attributed to the reported differences in environmental conditions during the seed development, genetic background, maturity, and agricultural practices. The 
Table 3. Fatty acid composition of the six quinoa genotypes ( $\left.\mathrm{g} .100 \mathrm{~g}^{-1} \mathrm{fat}\right)$.

\begin{tabular}{|c|c|c|c|c|c|c|}
\hline \multicolumn{7}{|c|}{ Genotypes } \\
\hline \multirow{2}{*}{ Fatty acids } & \multicolumn{2}{|c|}{ North } & \multicolumn{2}{|c|}{ Centre } & \multicolumn{2}{|c|}{ South } \\
\hline & Ancovinto & Cancosa & Cáhuil & Faro & Regalona & Villarrica \\
\hline \multicolumn{7}{|l|}{ Saturated fatty acids } \\
\hline Mysristic (C14:00) & ND & $0.13 \pm 0.01^{\mathrm{a}}$ & $0.16 \pm 0.01^{\mathrm{b}}$ & $0.184 \pm 0.01^{c}$ & $0.21 \pm 0.02^{\mathrm{d}}$ & $0.25 \pm 0.01^{\mathrm{e}}$ \\
\hline Pentadecanoic (C15:0) & ND & $0.04 \pm 0.00^{\mathrm{ab}}$ & $0.04 \pm 0.01^{\mathrm{a}}$ & $0.044 \pm 0.00^{\mathrm{abc}}$ & $0.05 \pm 0.00^{c}$ & $0.04 \pm 0.00^{\mathrm{bc}}$ \\
\hline Palmitic (C16:0) & $7.87 \pm 0.05^{\mathrm{a}}$ & $8.14 \pm 0.06^{\mathrm{b}}$ & $8.32 \pm 0.56^{\mathrm{ab}}$ & $8.192 \pm 0.11^{\mathrm{ab}}$ & $8.56 \pm 0.27^{\mathrm{bc}}$ & $8.97 \pm 0.05^{c}$ \\
\hline Heptadecanoic (C17:0) & $0.05 \pm 0.00^{\mathrm{a}}$ & $0.04 \pm 0.00^{\mathrm{b}}$ & $0.03 \pm 0.00^{c}$ & ND & ND & $0.03 \pm 0.00^{c}$ \\
\hline Estearic (C18:0) & $0.75 \pm 0.06^{\mathrm{a}}$ & $0.70 \pm 0.02^{\mathrm{ab}}$ & $0.63 \pm 0.02^{\mathrm{cd}}$ & $0.669 \pm 0.00^{\mathrm{bc}}$ & $0.61 \pm 0.01^{\mathrm{d}}$ & $0.54 \pm 0.01^{\mathrm{e}}$ \\
\hline Heneicosanoic (C21:0) & $0.03 \pm 0.00^{\mathrm{a}}$ & $0.04 \pm 0.01^{\mathrm{a}}$ & $0.06 \pm 0.01^{\mathrm{ab}}$ & $0.0596 \pm 0.03^{\mathrm{ab}}$ & $0.10 \pm 0.06^{\mathrm{b}}$ & $0.05 \pm 0.01^{\mathrm{a}}$ \\
\hline Tricosanoic (C23:0) & $4.44 \pm 0.45^{\mathrm{a}}$ & $3.49 \pm 0.24^{\mathrm{a}}$ & $4.30 \pm 1.00^{\mathrm{a}}$ & $4.8793 \pm 1.28^{\mathrm{a}}$ & $6.81 \pm 1.51^{\mathrm{b}}$ & $3.79 \pm 0.54^{\mathrm{a}}$ \\
\hline Lignoceric(C24:0) & $0.23 \pm 0.04^{\mathrm{a}}$ & $0.22 \pm 0.03^{\mathrm{a}}$ & $0.23 \pm 0.03^{\mathrm{a}}$ & $0.2642 \pm 0.06^{\mathrm{a}}$ & $0.24 \pm 0.04^{\mathrm{a}}$ & $0.27 \pm 0.05^{\mathrm{a}}$ \\
\hline \multicolumn{7}{|l|}{ Unsaturated fatty acids } \\
\hline Palmitoleic (C16:1) & $0.04 \pm 0.00^{\mathrm{ab}}$ & $0.06 \pm 0.00^{\mathrm{b}}$ & $0.03 \pm 0.01^{\mathrm{a}}$ & $0.05 \pm 0.01^{\mathrm{ab}}$ & $0.05 \pm 0.02^{\mathrm{ab}}$ & $0.06 \pm 0.01^{\mathrm{b}}$ \\
\hline Heptadecaenoic (C17:1) & $0.05 \pm 0.00^{\mathrm{a}}$ & $0.05 \pm 0.00^{\mathrm{a}}$ & $0.08 \pm 0.05^{\mathrm{a}}$ & $0.06 \pm 0.04^{\mathrm{a}}$ & $0.06 \pm 0.03^{\mathrm{a}}$ & $0.04 \pm 0.01^{\mathrm{a}}$ \\
\hline Oleic (C18:1) & $27.87 \pm 0.02^{\mathrm{a}}$ & $26.91 \pm 0.24^{\mathrm{b}}$ & $23.45 \pm 0.14^{c}$ & $22.25 \pm 0.29^{\mathrm{d}}$ & $18.68 \pm 0.27^{\mathrm{e}}$ & $20.77 \pm 0.26^{\mathrm{f}}$ \\
\hline Linoleic (C18:2) & $45.17 \pm 0.39^{\mathrm{a}}$ & $46.57 \pm 0.06^{\mathrm{b}}$ & $52.90 \pm 0.59^{c}$ & $53.89 \pm 0.93^{\text {cd }}$ & $54.18 \pm 0.95^{\mathrm{d}}$ & $53.36 \pm 0.62^{\mathrm{cd}}$ \\
\hline Gamma Linolenic (C18:3) & $0.51 \pm 0.04^{\mathrm{a}}$ & $0.50 \pm 0.02^{\mathrm{a}}$ & $0.49 \pm 0.05^{\mathrm{a}}$ & $0.48 \pm 0.00^{\mathrm{a}}$ & $0.43 \pm 0.02^{\mathrm{a}}$ & $0.34 \pm 0.26^{\mathrm{a}}$ \\
\hline Alpha Linolenic (C18:3) & $8.30 \pm 0.20^{\mathrm{a}}$ & $8.27 \pm 0.13^{\mathrm{a}}$ & $5.45 \pm 0.12^{\mathrm{b}}$ & $4.64 \pm 0.20^{c}$ & $5.35 \pm 0.26^{\mathrm{b}}$ & $5.88 \pm 0.23^{\mathrm{d}}$ \\
\hline Eicosenoic $(\mathrm{C} 20: 1)$ & $1.61 \pm 0.01^{\mathrm{a}}$ & $1.69 \pm 0.06^{\mathrm{b}}$ & $1.34 \pm 0.06^{c}$ & $1.45 \pm 0.01^{\mathrm{d}}$ & $1.45 \pm 0.02^{\mathrm{d}}$ & $1.61 \pm 0.03^{\mathrm{a}}$ \\
\hline Eicosadienoic (C20:2) & $0.31 \pm 0.01^{\mathrm{ab}}$ & $0.33 \pm 0.02^{\mathrm{a}}$ & $0.25 \pm 0.01^{c}$ & $0.26 \pm 0.01^{c}$ & $0.29 \pm 0.01^{\mathrm{b}}$ & $0.30 \pm 0.00^{\mathrm{b}}$ \\
\hline Dihomogammalinolenic (C20:3) & $0.66 \pm 0.06^{\mathrm{a}}$ & $0.65 \pm 0.07^{\mathrm{a}}$ & $0.64 \pm 0.07^{\mathrm{a}}$ & $0.67 \pm 0.07^{\mathrm{a}}$ & $0.64 \pm 0.07^{\mathrm{a}}$ & $0.68 \pm 0.09^{\mathrm{a}}$ \\
\hline Eicosatrienoic (C20:3) & $1.43 \pm 0.03^{\mathrm{a}}$ & $1.55 \pm 0.12^{\mathrm{ab}}$ & $1.08 \pm 0.07^{c}$ & $1.28 \pm 0.06^{\mathrm{d}}$ & $1.66 \pm 0.10^{\mathrm{b}}$ & $1.85 \pm 0.04^{\mathrm{e}}$ \\
\hline Arachidonic (C20:4) & $0.09 \pm 0.01^{\mathrm{ab}}$ & $0.09 \pm 0.01^{\mathrm{ab}}$ & $0.06 \pm 0.00^{c}$ & ND & $0.11 \pm 0.04^{\mathrm{a}}$ & $0.08 \pm 0.00^{\mathrm{bc}}$ \\
\hline Docosadienoic (C22:2) & $0.12 \pm 0.01^{\mathrm{a}}$ & $0.13 \pm 0.01^{\mathrm{a}}$ & $0.12 \pm 0.02^{\mathrm{a}}$ & $0.12 \pm 0.01^{\mathrm{a}}$ & $0.16 \pm 0.01^{\mathrm{b}}$ & $0.20 \pm 0.01^{c}$ \\
\hline Nervonic (C24:1) & $0.15 \pm 0.01^{\mathrm{a}}$ & $0.18 \pm 0.01^{\mathrm{b}}$ & $0.13 \pm 0.01^{\mathrm{c}}$ & $0.15 \pm 0.01^{\mathrm{a}}$ & $0.19 \pm 0.02^{\mathrm{b}}$ & $0.25 \pm 0.01^{\mathrm{d}}$ \\
\hline
\end{tabular}

Different letters in the same lines indicate that the values are significantly different $(p<0.05)$; ND : not detected.

fatty acid profile of all quinoa genotypes showed that these lipids are a good source of the nutritionally essential linoleic and oleic acids. Linoleic acid was the predominat fatty acid (45.17-54.18 g.100 g-1 fat), followed by oleic acid, palmitic acid, and alpha linoleic acid. This trend was similar to those found in other studies (ANDO et al., 2002; DINI et al., 1992). The presence of high amount of linoleic acid suggests that quinoa can be used as a good source of essential fatty acid (NYAM et al., 2009). Linoleic, oleic, and linolenic acids are the most important essential fatty acids required for growth, physiological functions, and cell maintenance (ABUGOCH, 2009). Oleic acid is the second most common fatty acid, between $18.68 \mathrm{~g} .100 \mathrm{~g}^{-1}$ fat for Regalona variety and $27.87 \mathrm{~g} .100 \mathrm{~g}^{-1}$ fat for Ancovinto genotype. The content of alpha linolenic acid was $4.64 \mathrm{~g} .100 \mathrm{~g}^{-1}$ fat for Faro genotype and $8.30 \mathrm{~g} .100 \mathrm{~g}^{-1}$ fat for Ancovinto genotype, and the content of palmitic acid was $7.87 \mathrm{~g} .100 \mathrm{~g}^{-1}$ fat and $8.97 \mathrm{~g} .100 \mathrm{~g}^{-1}$ fat for Ancovinto and Villarrica, respectively. The other fatty acids were found in small quantities. Ando et al. (2002) found linoleic acid (C18:2) to be the principal fatty acid $\left(52.0 \mathrm{~g} .100 \mathrm{~g}^{-1}\right.$ fat) in quinoa grown in Bolivia, followed by oleic acid (C18:1) (25.6 g.100 g-1 fat), palmitic acid (C16:0) (10.3 g.100 g $\mathrm{g}^{-1}$ fat), and linolenic acid (C18:3) (9.8 g.100 g $\mathrm{g}^{-1}$ fat).

In the last decades, unsaturated fatty acids have gained importance because of various beneficial functions. For example, they play a very important role in maintaining the fluidity of cell membranes (REPO-CARRASCO; ESPINOZA; JACOBSEN, 2003). In the present study, most of the fatty acids found in all genotypes were unsaturated fatty acids $\left(83.26-87.0\right.$ g. $100 \mathrm{~g} \mathrm{~g}^{-1}$ fat), while saturated fatty acids (mainly, palmitic acid) had a slight contribution to the total fatty acids content. The high levels of unsaturated fatty acids was higher than those reported by Dini et al. (1992), who found that $71.5 \mathrm{~g} .100 \mathrm{~g}^{-1}$ fat of the total fatty acids of quinoa were unsaturated.

\subsection{Determination of amino acids}

Protein nutritional quality is determined by the proportions of essential amino acids, which cannot be synthesized by animals and hence must be provided in the diet. Ten amino acids are strictly essential: lysine, isoleucine, leucine, phenylalanine, tyrosine, threonine, tryptophan, valine, histidine, and methionine. However, cysteine is also often included in this list since it can only be synthesized from methionine (which is itself essential) and plants show combined values for these sulphur-containing amino acids (VEGA-GÁLVEZ et al., 2010a). The content of amino acids (Table 4) was similar to that found by Wright et al. (2002). Thus, the genetic characteristic of the quinoa genotypes decisively influences the profile of the amino acids. Villarrica genotype had the highest content of most amino acids (histidine, leucine, lysine, methionine, phenylalanine, tyrosine, taurina, glycine, and serine). In contrast, the lowest 
Table 4. Amino acid composition of six quinoa genotypes ( $\mathrm{g} .100 \mathrm{~g}^{-1}$ protein).

\begin{tabular}{|c|c|c|c|c|c|c|}
\hline \multicolumn{7}{|c|}{ Genotypes } \\
\hline & \multicolumn{2}{|c|}{ North } & \multicolumn{2}{|c|}{ Centre } & \multicolumn{2}{|c|}{ South } \\
\hline & Ancovinto & Cancosa & Cáhuil & Faro & Regalona & Villarrica \\
\hline \multicolumn{7}{|l|}{ Essential } \\
\hline Isoleucine & $3.8 \pm 0.2^{\mathrm{a}}$ & $3.4 \pm 0.1^{\mathrm{b}}$ & $2.9 \pm 0.3^{c}$ & $3.4 \pm 0.3^{\mathrm{b}}$ & $3.0 \pm 0.1^{\mathrm{c}}$ & $3.1 \pm 0.1^{b c}$ \\
\hline Leucine & $6.8 \pm 0.2^{\mathrm{abc}}$ & $6.5 \pm 0.0^{\mathrm{a}}$ & $6.4 \pm 0.4^{\mathrm{a}}$ & $7.0 \pm 0.2^{\mathrm{bc}}$ & $6.6 \pm 0.1^{\mathrm{ab}}$ & $7.2 \pm 0.1^{\mathrm{c}}$ \\
\hline Phenylalanine & $4.1 \pm 0.2^{\mathrm{ab}}$ & $3.9 \pm 0.0^{\mathrm{a}}$ & $3.9 \pm 0.2^{\mathrm{a}}$ & $4.2 \pm 0.2^{\mathrm{bc}}$ & $4.0 \pm 0.1^{\mathrm{a}}$ & $4.5 \pm 0.2^{c}$ \\
\hline Tyrosine & $2.8 \pm 0.1^{\mathrm{a}}$ & $2.8 \pm 0.2^{\mathrm{ab}}$ & $3.1 \pm 0.2^{\mathrm{cd}}$ & $3.3 \pm 0.3^{\mathrm{d}}$ & $2.9 \pm 0.1^{\mathrm{abc}}$ & $3.1 \pm 0.2^{\mathrm{bcd}}$ \\
\hline Threonine & $3.5 \pm 0.1^{\mathrm{ac}}$ & $3.2 \pm 0.0^{\mathrm{b}}$ & $3.3 \pm 0.0^{\mathrm{ab}}$ & $3.6 \pm 0.3^{c}$ & $3.3 \pm 0.1^{\mathrm{ab}}$ & $3.4 \pm 0.1^{\mathrm{ab}}$ \\
\hline Valine & $4.9 \pm 0.2^{\mathrm{a}}$ & $4.6 \pm 0.1^{\mathrm{ab}}$ & $4.7 \pm 0.3^{\mathrm{ab}}$ & $4.9 \pm 0.2^{\mathrm{a}}$ & $4.3 \pm 0.1^{\mathrm{b}}$ & $4.4 \pm 0.1^{\mathrm{b}}$ \\
\hline \multicolumn{7}{|l|}{ Non-essential } \\
\hline Glutamic acid & $10.9 \pm 0.4^{\mathrm{abc}}$ & $10.8 \pm 0.3^{\mathrm{ab}}$ & $10.7 \pm 0.3^{\mathrm{a}}$ & $11.0 \pm 0.7^{\mathrm{abc}}$ & $11.5 \pm 0.2^{\mathrm{c}}$ & $11.4 \pm 0.3^{b c}$ \\
\hline Glycine & $4.4 \pm 0.3^{\mathrm{a}}$ & $4.5 \pm 0.2^{\mathrm{a}}$ & $5.3 \pm 0.5^{\mathrm{b}}$ & $5.4 \pm 0.5^{\mathrm{bc}}$ & $5.4 \pm 0.5^{\mathrm{b}}$ & $6.1 \pm 0.2^{c}$ \\
\hline Proline & $7.1 \pm 0.4^{\mathrm{ab}}$ & $7.7 \pm 0.1^{\mathrm{b}}$ & $9.4 \pm 0.7^{c}$ & $9.0 \pm 0.4^{c}$ & $7.4 \pm 0.0^{\mathrm{ab}}$ & $6.7 \pm 0.2^{\mathrm{a}}$ \\
\hline Serine & $4.2 \pm 0.2^{\mathrm{a}}$ & $4.1 \pm 0.1^{\mathrm{a}}$ & $4.1 \pm 0.1^{\mathrm{a}}$ & $4.4 \pm 0.4^{\mathrm{ab}}$ & $4.3 \pm 0.3^{\mathrm{a}}$ & $4.8 \pm 0.3^{\mathrm{b}}$ \\
\hline
\end{tabular}

a,b,c Different letters in the same lines indicate that the values are significantly different $(p<0.05)$.

content of amino acids was found for Cáhuil genotype. With respect to non essential amino acids, the most abundant in decreasing order were: glutamic acid, arginine, proline, aspartic acid, glycine, alanine, serine, and finally taurina. The amino acid level reported for quinoa genotypes in this study, with the exception of valine, alanine, methionine, and isoleucine, were similar to the levels reported by Dini et al. (1992) when working with quinoa var. Perlada from Peru. The content of essential amino acids in the protein of quinoa genotypes was high. According to Jancurová, Minarovicová and Dandár (2009), the level of each of these amino acids was higher in the protein of quinoa than in that of maize, rice, and wheat. Even higher values have been reported for lysine. Torrez, Guzmán and Carvajal (2002) reported values for lysine of 5.69-8.84 g.100 g $\mathrm{g}^{-1}$ protein, when working with ten varieties of quinoa from Bolivia.

\subsection{Determination of antioxidant activity}

In addition to evaluate the quinoa chemical composition, an additional aim of this study was to investigate its potential functionality in terms of antioxidant activity. The antioxidant activity of six quinoa genotypes has already been evaluated by DPPH method. The DPPH scavenging activities of the quinoa seed extracts are expressed as percentage inhibition. The DPPH radical scavenging activity of quinoa samples $\left(2.0 \mathrm{mg} \cdot \mathrm{mL}^{-1}\right)$ is shown in Figure 2. Faro genotype presented the best results (79.58\%), while Ancovinto genotype showed the worst results (35.61\%). The data variation in the antioxidant activity of quinoa genotypes was expected since many factors such as genetic, agro-technical processes, and environment conditions can influence the presence of phenolic compounds (ALVAREZ-

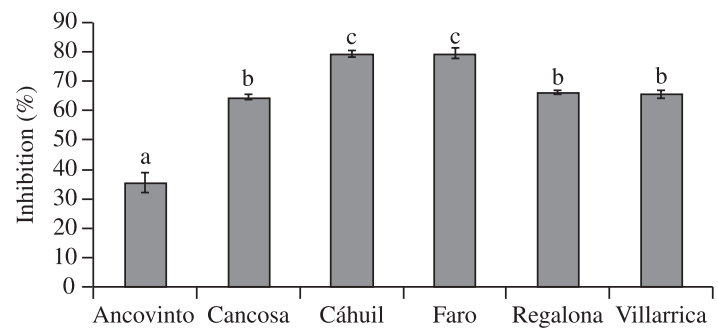

Figure 2. DPPH (2,2,-diphenyl-2-picryl-hydrazyl) free radical scavenging activity $\left(2.0 \mathrm{mg} \cdot \mathrm{mL}^{-1}\right)$ of six quinoa genotypes. ${ }^{\mathrm{a}, \mathrm{b}}$ Different letters above the bars indicate that the values are significantly different $(\mathrm{p}<0.05)$.

JUBETE et al., 2010; NSIMBA; KIKUZAKI; KONISHI, 2008). Nsimba, Kikuzaki and Konishi, (2008) studied the antioxidant activity of different genotypes of quinoa from Japan and Bolivia using the DPPH method. They found $\mathrm{IC}_{50}$ values between 100$7500 \mu \mathrm{g} \cdot \mathrm{mL}^{-1}$ of genotypes from Japan and $300-15800 \mu \mathrm{g} \cdot \mathrm{mL}^{-1}$ or the genotypes from Bolivia.

\section{Conclusions}

This study reveals great genetic differentiation among the geographic distribution of quinoa genotypes in Chile. Such differences are confirmed by morphological and yield responses in a common garden assay of six selected genotypes. The two northern Altiplano genotypes were genetically, morphologically, and agronomically different from the rest of the centralsouthern Chilean quinoa genotypes. The six genotypes studied showed different nutritional composition, sugar content, 
fatty acid, amino acid composition, and antioxidant activity. Villarrica genotype was characterized by exhibiting higher protein content, dietary fiber, and essential amino acids. The antioxidant activity among the quinoa seed extracts were the highest in Faro genotype.

\section{Acknowledgements}

This research was financed by Fondecyt Grant 1100638. We gratefully acknowledge Arturo Prat University (Iquique, Chile), Cooperativa Agricola Las Nieves, Ingrid Von Bear (Agrogen Ltda) and to Gabriel Curilef P., Agrupación de Productores Agroécologicos We Mapu for donation of seed samples.

\section{References}

ABUGOCH, L. E. Quinoa (Chenopodium quinoa Willd.): Composition, Chemistry, Nutritional and Functional Properties. Advances in Food and Nutrition Research, v. 58, p. 1-31, 2009.

ALVAREZ-JUBETE, L. et al. Polyphenol composition and in nitro antioxidant activity of amaranth, quinoa, buckwheat and wheat as affected by sprouting and baking. Food Chemistry, v. 119, p. 770-778, 2010. http://dx.doi.org/10.1016/j.foodchem.2009.07.032

ANDO, H. et al. Food Components in Fractions of Quinoa Seed. Food Science and Technology Research, v. 8, n. 1, p. 80-84, 2002. http:// dx.doi.org/10.3136/fstr.8.80

ASSOCIATION OF OFFICIAL ANALYTICAL CHEMISTS - AOAC. Official Method of Analysis. 15th ed. Washington: AOAC, 1990.

ARANDA, M.; VEGA, M.; VILLEGAS, F. Routine method for quantification of Starch by planar chromatography (HPTLC). Journal of Planar Chomatography, v. 18, p. 285-289, 2005. http:// dx.doi.org/10.1556/JPC.18.2005.4.6

BARIKMO, I.; OUATTARA, F.; OSHAUG, A. Protein, carbohydrate and fibre in cereals from Mali-how to fit the results in a food composition table and database. Journal of Food Composition and Analysis, v. 17, p. 291-300, 2004. http://dx.doi.org/10.1016/j. jfca.2004.02.008

BERTERO, H. D.; KING, R. W.; HALLA, A. J. Modelling photoperiod and temperature responses of flowering in quinoa (Chenopodium quinoa Willd.). Field crops research, v. 63, p.19-34, 1999. http:// dx.doi.org/10.1016/S0378-4290(99)00024-6

CHAUHAN, G. S.; ESKIN, N. A. M.; TKACHUK, R. Nutrients and Antinutrients in Quinoa Seed. Cereal Chemistry, v. 69, n. 1, p. 85-88, 1992.

DINI, A. et al. A compositional study of Chenopodium quinoa seeds. Dic Nahrung, v. 36, p. 400-404, 1992. http://dx.doi.org/10.1002/ food. 19920360412

DINI, I.; TENORE, G. C.; DINI, A. 2005. Nutricional amd antinutritional composition of Kancolla seeds: an interesting and underexploited andine food plant. Food Chemistry, v. 92, p. 125-132, 2005. http://dx.doi.org/10.1016/j.foodchem.2004.07.008

DINI, I., TENORE, G. C., DINI, A., 2010. Antioxidant compound contents and antioxidant activity befote and alter cooking in sweet and bitter Chenopodium quinoa seeds. LWT-Food Sience and Technology, v. 43, p. 447-451, 2010. http://dx.doi.org/10.1016/j. lwt.2009.09.010

FUENTES, F. et al. Assessment of genetic diversity patterns in Chilean quinoa (Chenopodium quinoa Willd.) germplasm using multiplex flourescent microsatellites markers. Conservation Genetics, v. 10, p. 369-377, 2009. http://dx.doi.org/10.1007/s10592-008-9604-3
FUENTES, F.; BHARGAVA, A. Morphological Analysis of Quinoa Germplasm Grown Under Lowland Desert Conditions. Journal of Agronomy and Crop Science, v. 197, p. 124-134, 2011. http:// dx.doi.org/10.1111/j.1439-037X.2010.00445.x

INFOSTAT. InfoStat versión 2008. Córdoba: Grupo InfoStat, FCA, Universidad Nacional de Córdoba.

JANCUROVÁ, M.; MINAROVICOVÁ, L.; DANDÁR, A. Quinoa-a Review. Czech Journal of Food Science, v. 27, n. 2, p. 71-79, 2009.

MARTÍNEZ, E. A.; DELATORRE, J.; VON BAER, I. Quínoa: las potencialidades de un cultivo sub-utilizado en Chile. Tierra Adentro (INIA), v. 75, p. 24-27, 2007.

MARTÍNEZ, E. A. et al. Re-Introduction of Quínoa into Arid Chile: Cultivation of Two Lowland Races under Extremely Low Irrigation. Journal of Agronomy and Crop Science, v. 195, p. 1-10, 2009. http://dx.doi.org/10.1111/j.1439-037X.2008.00332.x

MIRANDA, M. et al. Impact of air-drying temperature on nutritional properties, total phenolic content and antioxidant capacity of quinoa seeds (Chenopodium quinoa Willd.). Industrial Crops and Products, v. 32, p. 258-263, 2010. http://dx.doi.org/10.1016/j. indcrop.2010.04.019

NSIMBA, R. Y.; KIKUZAKI, H.; KONISHI, Y. Antioxidant activity of various extracts and fractions of Chenopodium quinoa and Amaranthus spp.seeds. Food Chemistry, v. 106, p. 760-766, 2008. http://dx.doi.org/10.1016/j.foodchem.2007.06.004

NYAM, K. L. et al. Physicochemical properties and bioactive compounds of selected seed oils. LWT - Food Science and Technology, v. 42, p. 1396-1403, 2009.

PATZSCH, K.; NETZ, S.; FUNK, W. Quantitative HPTLC of sugers part 1: separation and derivatization. Journal of Planar Chromatography, v. 1, p. 39-45, 1988.

REPO-CARRASCO, R.; ESPINOZA, C.; JACOBSEN, S. E. Nutricional Value and Use of the Andean Crops Quinoa (Chenopodium quinoa) and Kañiwa (Chenopodium pallidicaule). Food Reviews International, v. 19, p. 179-189, 2003. http://dx.doi.org/10.1081/ FRI-120018884

REPO-CARRASCO-VALENCIA, R.; SERNA, L. A. Quinoa (Chenopodium quinoa, Willd.) as a source of dietary fiber and other functional components. Ciência e Tecnologia de Alimentos, v. 31, n. 1, p. 225-230, 2011. http://dx.doi.org/10.1590/S010120612011000100035

REPO-CARRASCO-VALENCIA, R. et al. Flavonoids and other phenolic compounds in Andean indigenous grains: Quinoa (Chenopodium quinoa), kañiwa (Chenopodium pallidicaule) and kiwicha. Food Chemistry, v. 120, p. 128-133, 2010. http://dx.doi. org/10.1016/j.foodchem.2009.09.087

REPO-CARRASCO-VALENCIA, R. et al. Chemical and Functional Characterization of Kañiwa (Chenopodium palladicaule) grain, Extrudate and Bran. Plant Food for Human Nutrition, v. 64, p. 94-101, 2009a. http://dx.doi.org/10.1007/s11130-009-0109-0

REPO-CARRASCO-VALENCIA, R. et al. Dietary fiber and other functional components in two varieties of crude and extruded kiwicha (Amaranthus caudatus). Journal of Cereal Science, v. 49, p. 219-224, 2009b. http://dx.doi.org/10.1016/j.jcs.2008.10.003

RUIZ-CARRASCO, K. et al. Variation in salinity tolerance of four lowland genotypes of quinoa (Chenopodium quinoa Willd.) as assessed by growth, physiological traits, and sodium transporter gene expression. Plant Physiology and Biochemistry, v. 49, n. 11, p. 1333-1341, 2011. http://dx.doi.org/10.1016/j.plaphy.2011.08.005 
TORREZ, M. O.; GUZMÁN, A. A.; CARVAJAL, R. Valoración nutricional de 10 variedades de Quinua (Chenopodium quinoa Willd) del altiplano boliviano. BIOFARBO, p. 55-60, 2002.

TURKMEN, N.; SARI, F.; VELIOGLU, Y. S. The effect of cooking methods on total phenolics and antioxidant activity of selected green vegetables. Food Chemistry, v. 93, p. 713-718, 2005. http:// dx.doi.org/10.1016/j.foodchem.2004.12.038

VEGA-GÁLVEZ, A. et al. 2010a. Nutrition facts and functional potential of quinoa (Chenopodium quinoa Willd.). An ancient Andean grain: A review. Journal of the Science of Food and
Agriculture, v. 90, p. 2541-2547, 2010a. http://dx.doi.org/10.1002/ jsfa. 4158

VEGA-GÁLVEZ, A. et al. Characteristics and Mathematical Modeling of convective drying of quinoa (Chenopodium quinoa willd.): Influence of temperature on the kinetic parameters. Journal of Food Processing and Preservation, v. 34, n. 6, 945-963, 2010b. http:// dx.doi.org/10.1111/j.1745-4549.2009.00410.x

WRIGHT, K. H. et al. Composition of Atriplex hortensis, Sweet and Bitter Chenopodium quinoa Seeds. Food Chemistry and Toxicology, v. 67 , n. 4, p. 1383-1385, 2002. http://dx.doi. org/10.1111/j.1365-2621.2002.tb10294.x 